\title{
PIPERACILLIN COMBINED WITH AZITHROMYCIN IN THE TREATMENT OF CHILDHOOD MYCOPLASMA PNEUMONIAE PNEUMONIA AND THE INFLUENCE ON THE INTESTINAL MICROECOLOGY
}

\author{
NA QIN ${ }^{1}$, GUOYAN YIN ${ }^{1}$, LIJUAN CHEN $^{1}$, NAN PING ${ }^{1}$, SIHUI ZHAO ${ }^{1}$, HUIBIN $_{\text {QIN }}{ }^{2} *$ \\ ${ }^{1}$ Department of Paediatrics, Heping Hospital Affiliated to Changzhi Medical College, Changzhi, 046000, Shanxi, China \\ ${ }^{2}$ Department of Stomatology, Heping Hospital Affiliated to Changzhi Medical College, Changzhi, 046000, Shanxi, China
}

*corresponding author: qinhuibin@tom.com

Manuscript received: September 2020

\begin{abstract}
This study aimed to investigate the clinical effect of piperacillin combined with azithromycin in the treatment of childhood Mycoplasma pneumoniae pneumonia (CMP). Forty-eight children patients with Mycoplasma pneumoniae pneumonia were divided into two groups: a control group and an experimental group, according to the random number table method. Children patients in the control group were treated with $10 \mathrm{mg} / \mathrm{kg}$ bw/day azithromycin by intravenous drip for three consecutive days, and then $5 \mathrm{mg} / \mathrm{kg}$ bw/day azithromycin orally for 4 days. The patients in the treatment group received $143 \mathrm{mg} / \mathrm{kg}$ bw/day piperacillin intravenously for 1 week combined with the same regiment of azithromycin as in the control group. The therapeutic effect, defervescence time, disappearance time of cough, disappearance time of lung sound, absorption time of chest radiograph, lung function indexes and related inflammatory factors before and after treatment, intestinal microecology, and drug adverse reaction rate were compared among children patients in the two groups. Piperacillin combined with azithromycin in the treatment of CMP greatly improved the clinical symptoms and lung function and reduced the levels of inflammatory factors, leading to mild adverse reactions compared with the treatment with azithromycin alone. However, the effect of combined treatment on the destruction of intestinal microecological balance was higher compared with the treatment with azithromycin alone.
\end{abstract}

\section{Rezumat}

Acest studiu a avut ca scop investigarea efectului clinic al piperacilinei combinată cu azitromicina în tratamentul pneumoniei pediatrice cauzate de Mycoplasma pneumoniae (CMP). Patruzeci și opt de copii diagnosticați cu pneumonie au fost împărțiţi aleator în două grupuri: un grup de control și un grup experimental. Copiii din grupul control au fost trataţi cu $10 \mathrm{mg} / \mathrm{kg}$ corp/zi azitromicină pe cale intravenoasă trei zile consecutive şi apoi $5 \mathrm{mg} / \mathrm{kg}$ corp/zi azitromicină pe cale orală timp de 4 zile. Pacienţii din grupul de tratament au primit $143 \mathrm{mg} / \mathrm{kg}$ corp/zi piperacilină, intravenos timp de o săptămână, combinat cu același regim de azitromicină ca în grupul control. Efectul terapeutic, timpul de defervescență, timpul de dispariție a tusei, timpul de dispariție a sunetului pulmonar, timpul de absorbție a radiografiei toracice, indicii funcției pulmonare și factorii inflamatori asociați înainte şi după tratament, microecologia intestinală şi rata reacțiilor adverse la medicamente au fost comparate la copiii din cele două grupuri. Piperacilina combinată cu azitromicină în tratamentul CMP a îmbunătățit semnificativ simptomele clinice şi funcția pulmonară și a redus nivelul markerilor inflamatori, ducând la reacții adverse uşoare comparativ cu tratamentul cu azitromicină singură. $\mathrm{Cu}$ toate acestea, efectul tratamentului combinat asupra distrugerii echilibrului microecologic intestinal a fost mai mare comparativ cu tratamentul cu azitromicină singură.

Keywords: childhood mycoplasmal pneumonia, piperacillin, azithromycin, intestinal flora

\section{Introduction}

Neonatal pneumonia is a common respiratory infectious disease in clinical practice, and its main clinical manifestations in children patients are cough, cyanosis, and breathing difficulty. Moreover, it has a high fatality rate so antibiotic treatment is essential for a good prognosis $[1,2]$. In recent years, antibiotics have been widely applied in the treatment of neonatal pneumonia to achieve significant efficacy, so it markedly reduces the mortality of children with neonatal pneumonia. However, antibiotics are abused in clinical treatment, or the influence of antibiotics on the intestinal microecological balance of children is not taken into account when they are selected [3, 4]. Therefore, effective treatment of mycoplasmal pneumonia can help children recover and grow healthy. Mycoplasma pneumoniae is a slightly known individual microorganism that exists between viruses and bacteria [5]. It has the characteristics of ribonucleic acid (RNA) and deoxyribonucleic acid (DNA)-related biology and lacks cell walls in its structure $[6,7]$, so penicillins or cephalosporins have no substantial effect on the treatment of this disease [8]. Macrolide antibiotics can block the transpeptidase related action and interfere with the displacement of messenger RNA (mRNA) 
generation, thus inhibiting the bacterial protein-related synthesis $[9,10]$. In modern clinical practice, such antibiotics are generally not selected for the clinical treatment of mycoplasmal pneumonia infection in children, because of the impact of quinolines on the osteogenic development of children [11]. Azithromycin is generally selected for the treatment in modern clinical practice, and its therapeutic effect has been confirmed by paediatric doctors and patients. Although, macrolides are the preferred drugs in the treatment of CMP, azithromycin is still mostly selected for this treatment due to fewer adverse reactions and lower drug resistance [12]. In this study, the therapeutic effect of piperacillin combined with azithromycin in the treatment of CMP was assessed and reported as follows.

\section{Materials and Methods}

\section{Basic data of the children patients}

According to the random number table method, 48 children with Mycoplasma pneumoniae pneumonia, admitted to the Heping Hospital Affiliated to Changzhi Medical College between February 2019 and May 2020, were divided into two groups. In the experimental group, there were 11 males and 13 females aged 2 - 9 years old (average age of $6.85 \pm 4.72$ years old), and the onset time was 3 - 8 days (average time of $5.07 \pm$ 2.45 days). In the control group, there were 12 males and 12 females with the age of 2 - 10 years old (average age of $6.72 \pm 4.55$ years old), and the onset time ranged from 3 days to 9 days (average time of $5.18 \pm 2.28$ days). There was no significant difference in basic data among children patients of the two groups ( $p>0.05)$. The study has been approved by the Ethical Committee of the Heping Hospital Affiliated to Changzhi Medical College and an informed consent was obtained from the tutor of each child for participation in the study.

Therapeutic methods

In the control group, the children patients received 10 $\mathrm{mg} / \mathrm{kg}$ bw/day azithromycin (Jiangxi Huiren Pharmaceutical Co. Ltd., China) intravenously for 3 consecutive days and then $5 \mathrm{mg} / \mathrm{kg}$ bw/day azithromycin orally for 4 days. The children patients from the experimental group received the same regiment of azithromycin as in the control group plus $143 \mathrm{mg} / \mathrm{kg}$ bw/day piperacillin intravenously twice a day for 7 days. Piperacillin (Qilu Pharmaceutical Co., Ltd., China) was dissolved into $100 \mathrm{~mL}$ normal saline and administered intravenously. Observation indexes

The therapeutic effects in the two groups were compared, as well as defervescence time, disappearance time of cough, disappearance time of lung sound, absorption time of chest radiograph, lung function indexes and related inflammatory factors before and after treatment, intestinal microecology, and incidence of adverse drug reactions.

The content of lung function indexes was as follows. JAEGER MasterScreen complete pulmonary function testing system (Vyaire Medical GmbH, Germany) was used to test the lung function of each child patient at 30 minutes after the child patient ate, without abdominal distension. There were two measurement procedures. One was a commonly applied measurement method when the child patient was instructed to breathe in a calm state and take a deep and strong inhalation at the end of the expiration, and then, the child was asked to slowly do the maximum exhalation until the residual breath was reached with a final strong inhalation. The second measurement method was done when the child was asked to do a forced exhalation action at the end of inhalation after calmly breathing and adapting, followed by a forced inhalation action, and finally, the child exhaled slowly to the residual air position. The measured value was analysed by a computer, and the lung function indexes checked mainly included the forced vital capacity (FVC), vital capacity in the first second (FEV1), and tidal volume V-T.

The inflammatory factors were determined using the corresponding kits for enzyme-linked immunosorbent assay (ELISA) according to the manufacturer instructions for serum interleukin (IL)-8, tumour necrosis factor (TNF) $-\alpha$ and C-reactive protein (CRP) levels (R\&D, USA).

The children faeces were collected and used to culture the intestinal flora using standard media (Guanggang, China) in order to analyse the expression of 4 probiotics (Lactobacillus, Bifidobacterium, Enterococcus and Eubacteriae) and one spoilage bacteria (Enterobacteriaceae) after the treatment. The results were expressed as the number of bacteria detected per gram of faeces.

Evaluation criteria of therapeutic effect had three aspects: the significant effect: which meant lung function indexes and related inflammatory factors reached normal levels and symptoms were significantly improved; the sufficient effect: lung function indexes and related inflammatory factors decreased, but did not reach the normal range, and symptoms were alleviated; no effect: there were no improvements in symptoms, lung function indexes, and related inflammatory factors. The total effective rate was calculated as follows:

Total effective rate $\%=$ (cases of significant effect + cases of sufficient effect)/total number of cases $\times 100$.

\section{Statistical methods}

SPSS 22.0 statistical software (IBM, USA) was used to analyse the data, Student's t-test was for the measurement data, and $\chi^{2}$ was applied to detect the enumeration data. A value of $\mathrm{p}<0.05$ indicated there was a statistically significant difference.

\section{Results and Discussion}

Clinical effect

The total effective rate of children patients in the experimental group was higher than the rate of the control group ( $\mathrm{p}<0.05)$, as shown in Table I. 
Therapeutic effects in the two patients groups

\begin{tabular}{ccccc}
\hline \multicolumn{1}{c}{ Group } & Significant effect & Sufficient effect & No effect & Total effective rate $(\%)$ \\
\cline { 2 - 5 } Control group & 21 & 17 & 10 & 79.17 \\
Experimental group & 32 & 15 & 1 & $97.92 *$ \\
\cline { 2 - 5 }
\end{tabular}

$* \mathrm{p}<0.05$ compared with the control group

Duration of symptom improvement

Table II showed that the defervescence time, disappearance time of cough, disappearance time of lung sound, and absorption time of chest radiograph of children patients in the experiment group were lower compared with the control group $(\mathrm{p}<0.05)$.

Table II

The duration of symptom improvement of children patients in the two groups

\begin{tabular}{lcccc}
\hline \multicolumn{1}{c}{ Group } & $\begin{array}{c}\text { Defervescence time } \\
\text { (day) }\end{array}$ & $\begin{array}{c}\text { Disappearance time of } \\
\text { cough (day) }\end{array}$ & $\begin{array}{c}\text { Disappearance time of } \\
\text { lung sound (day) }\end{array}$ & $\begin{array}{c}\text { Absorption time of } \\
\text { chest radiograph (day) }\end{array}$ \\
\hline Control group & $3.69 \pm 2.30$ & $7.39 \pm 2.11$ & $8.39 \pm 3.51$ & $4.42 \pm 2.21$ \\
Experimental group & $2.53 \pm 1.10^{*}$ & $5.52 \pm 1.21^{*}$ & $6.51 \pm 1.53^{*}$ & $3.11 \pm 1.10^{*}$ \\
\hline
\end{tabular}

$* \mathrm{p}<0.05$ compared with the control group

Lung function indexes and related inflammatory factors

Before treatment, lung function indexes and related inflammatory factors were similar among children patients in the 2 groups ( $\mathrm{p}>0.05)$. After treatment, lung function indexes and related inflammatory factors of children patients in the experimental group improved compared with the control group $(\mathrm{p}<0.05)$ (Table III).

Table III

Lung function indexes and related inflammatory factors of children patients in the two groups

\begin{tabular}{clcccc}
\hline \multirow{2}{*}{ Indexes } & \multicolumn{2}{c}{ Control group } & \multicolumn{2}{c}{ Experimental group } \\
\cline { 2 - 5 } & & Before treatment & After treatment & Before treatment & After treatment \\
\hline \multirow{3}{*}{ Lung function } & V-T $(\mathrm{mL} / \mathrm{kg})$ & $8.78 \pm 0.53$ & $9.97 \pm 0.51$ & $8.70 \pm 0.64$ & $12.48 \pm 0.85^{*}$ \\
& FEV1 $(\mathrm{L})$ & $1.25 \pm 0.23$ & $1.76 \pm 0.30$ & $1.31 \pm 0.29$ & $2.79 \pm 0.53^{*}$ \\
& FVC $(\mathrm{L})$ & $2.92 \pm 0.52$ & $3.88 \pm 0.47$ & $2.91 \pm 0.41$ & $4.47 \pm 0.59^{*}$ \\
& TNF- $\alpha(\mathrm{ng} / \mathrm{mL})$ & $15.02 \pm 0.93$ & $7.51 \pm 0.41$ & $14.95 \pm 0.88$ & $4.07 \pm 0.36^{*}$ \\
Inflammation & IL-8 $(\mathrm{ng} / \mathrm{mL})$ & $16.23 \pm 1.21$ & $7.51 \pm 0.89$ & $17.52 \pm 1.09$ & $3.73 \pm 0.54^{*}$ \\
& CRP $(\mathrm{mg} / \mathrm{L})$ & $9.63 \pm 0.57$ & $2.96 \pm 0.46$ & $9.42 \pm 0.59$ & $1.03 \pm 0.38^{*}$ \\
\hline
\end{tabular}

$* \mathrm{p}<0 . \overline{05}$ compared to the control group; $\mathrm{V}-\mathrm{T}=$ tidal volume; FEV1 = vital capacity in the first second; FVC = forced vital capacity; TNF- $\alpha=$ tumour necrosis factor alpha; IL- $8=$ Interleukin- 8 ; CRP = C-reactive protein

Intestinal microecology

After 1 week of treatment for children patients in the experiment group, the number of Lactobacillus, Bifidobacterium, Enterococcus and Eubacteria in the intestinal tracts decreased compared with the levels in the control group $(\mathrm{p}<0.05)$ while the number of Enterobacteriaceae (spoilage bacteria) significantly increased compared with the levels in the control group ( $\mathrm{p}<0.05)$ (Table IV).

Adverse reactions

Table $\mathrm{V}$ indicates that the adverse drug reactions rate of children patients in the experimental group decreased in contrast to the control group, but without reaching the statistical significance $(\mathrm{p}>0.05)$.

Table IV

Intestinal flora in children patients from the two groups after one week of treatment

\begin{tabular}{lcc}
\hline \multicolumn{1}{c}{ Group } & $\begin{array}{c}\text { Control } \\
\text { group }\end{array}$ & $\begin{array}{c}\text { Experimental } \\
\text { group }\end{array}$ \\
\hline Lactobacillus & $9.18 \pm 0.21$ & $8.56 \pm 0.28^{*}$ \\
Bifidobacterium & $9.85 \pm 0.36$ & $9.20 \pm 0.47^{*}$ \\
Enterococcus & $8.77 \pm 0.34$ & $8.25 \pm 0.18^{*}$ \\
Eubacteria & $9.62 \pm 0.29$ & $9.11 \pm 0.23^{*}$ \\
Enterobacteriaceae & $8.18 \pm 0.32$ & $9.07 \pm 0.35^{*}$ \\
\hline p $<0.05$ compared with the control group
\end{tabular}

Table V

Adverse reactions rate after the treatment, in the two groups

\begin{tabular}{lccccc}
\hline \multicolumn{1}{c}{ Group } & Nausea and vomiting & Elevated alanine aminotransferase & Diarrhoea & Skin rash & Incidence $(\%)$ \\
\hline Control group & 2 & 1 & 1 & 1 & $5(10.42)$ \\
Experimental group & 2 & 1 & 0 & 0 & $3(6.25)$ \\
\hline
\end{tabular}

Children pneumonia is usually accompanied by fever, cough, breathing difficulty, lung rales and shortness of breath and severe cases of pneumonia suffer from breathing difficulty or three depression signs [13]. It is necessary for a symptomatic treatment associated with the treatment that controls the pathogen infection. Ceftazidime is the main treatment applied in clinical treatment. It can control pathogen infection to a certain 
extent and reduce the patient's inflammation. Moreover, the studies showed that resistance to Ceftazidime is high because of the unreasonable application of antibiotics $[14,15]$. Piperacillin is a broad-spectrum semisynthetic penicillin acting as an irreversible competitive $\beta$-lactamase inhibitor. It has significant antibacterial effects on gram-positive and gram-negative bacilli and has a wide antibacterial spectrum, strong antibacterial effect and light toxic and adverse effects, which also has certain antibacterial effects on some drug-resistant bacilli [16-18]. Piperacillin, after entering the human body, can block the synthesis and activity of beta-lactamase, to inhibit the proliferation and diffusion of various pathogenic bacteria [19], and it can also interact with proteins on the surface of the pathogen to inhibit pathogens on the cell wall adhesion in the human respiratory system [20, 21]. Studies showed that it reduces the inflammatory injury of pathogens to children patients. Besides that, piperacillin has a fast mechanism of action and its toxicity to children is relatively low [22].

Azithromycin is a common macrolide drug that links to the pathogen transpeptidation and exerts its antibacterial effect by inhibiting protein synthesis [23]. Azithromycin combined with piperacillin can effectively promote the therapeutic effect and antibacterial activity to improve the symptoms and health state of children patients.

In this study, children patients in the control group were treated with azithromycin, while children patients in the experimental group were treated with a combination of piperacillin and azithromycin. The results showed that the total effective rate of children patients in the experimental group was higher compared with the levels in the control group $(p<0.05)$. The defervescence time, disappearance time of cough, disappearance time of lung sound, and absorption time of chest radiograph decreased in the experimental group compared with the control group $(\mathrm{p}<0.05)$. Before treatment, lung function indexes and related inflammatory factors of children patients in the two groups were similar $(p>0.05)$. After treatment, lung function indexes increased while the level of inflammatory factors decreased in the experimental group compared with the control group ( $p<0.05$ ). There was no significant difference in drug adverse reactions rate among children patients in the two groups ( $p>0.05$ ).

Besides that, the results of this study revealed that Bifidobacterium of intestinal flora in children patients was inhibited remarkably in the experimental group, and the number of Enterobacteriaceae increased. It was suggested that the combination of drugs would have an extreme impact on the intestinal microecology in children patients, mainly because piperacillin not only played a bactericidal role but also inhibited the intestinal beneficial bacteria to a certain extent, thus leading to the destruction of intestinal microecological balance. Therefore, it is necessary to apply antibiotics scientifically and rationally in clinical practice and associate them with probiotics that help preventing the detrimental effects of antibiotics [24-26].

\section{Conclusions}

In this clinical study, piperacillin combined with azithromycin in the treatment of CMP was effective to markedly improve the clinical symptoms and lung function, reduce the levels of inflammatory factors, and had no serious adverse reactions. However, they could destroy the intestinal microecological balance. Therefore, drug application should be scientific and rational in clinical treatment.

\section{Conflict of interest}

The authors declare no conflict of interest.

\section{References}

1. Chiu CY, Chen CJ, Wong KS, Tsai MH, Chiu CH, Huang YC, Impact of bacterial and viral coinfection on mycoplasmal pneumonia in childhood communityacquired pneumonia. J Microbiol Immunol Infect., 2015; 48(1): 51-56.

2. Zhao JL, Wang X, Wang YS, Relationships between Th1/Th2 cytokine profiles and chest radiographic manifestations in childhood Mycoplasma pneumoniae pneumonia. Ther Clin Risk Manag., 2016; 12: 16831692.

3. You SY, Jwa HJ, Yang EA, Kil HR, Lee JH, Effects of Methylprednisolone Pulse Therapy on Refractory Mycoplasma pneumoniae Pneumonia in Children. Allergy Asthma Immunol Res., 2014; 6(1): 22-26.

4. Blejan IE, Diaconu CC, Arsene AL, Udeanu DI, Ghica M, Drăgănescu D, Burcea Dragomiroiu GTA, Rădulescu M, Maltezou HC, Tsatsakis AM, Papasavva M, Drakoulis N, Popa DE, antibiotic resistance in community-acquired pneumonia. A Romanian perspective. Farmacia, 2020; 68(3): 512-520.

5. Li SL, Sun HM, Zhao HQ, Cao L, Yuan Y, Feng YL, Xue GH, A single tube modified allele-specificPCR for rapid detection of erythromycin-resistant Mycoplasma pneumoniae in Beijing. Chin Med J (Engl)., 2012; 125(15): 2671-2676.

6. Wolff BJ, Thacker WL, Schwartz SB, Winchell JM, Detection of macrolide resistance in Mycoplasma pneumoniae by real-time PCR and high-resolution melt analysis. Antimicrob Agents Chemother., 2008; 52(10): 3542-3549.

7. Kim HS, Sol IS, Li D, Choi M, Choi YJ, Lee KS, Seo JH, Lee YJ, Yang HJ, Kim HH, Efficacy of glucocorticoids for the treatment of macrolide refractory mycoplasma pneumonia in children: meta-analysis of randomized controlled trials. BMC Pulm Med., 2019; 19(1): 251: 1-14.

8. Li $\mathrm{Y}$, Cheng $\mathrm{H}$, Wang $\mathrm{H}$, Wang $\mathrm{Y}$, Liu L, Composite factors, including mycoplasmal pneumonia, hypersensitivity syndrome, and medicine, leading to bronchiolitis obliterans in a school-age child. Clin Pediatr (Phila), 2014; 53(14): 1409-1412.

9. Zhao F, Liu G, Wu J, Cao B, Tao X, He L, Meng F, Zhu L, Lv M, Yin Y, Surveillance of macrolide-resistant 
Mycoplasma pneumoniae in Beijing, China, from 2008 to 2012. Antimicrob Agents Chemother., 2013; 57(3): 1521-1523.

10. Chancey ST, Bai X, Kumar N, Drabek EF, Daugherty SC, Colon T, Ott S, Sengamalay N, Sadzewicz L, Tallon LJ, Fraser CM, Tettelin H, Stephens DS, Transcriptional attenuation controls macrolide inducible efflux and resistance in Streptococcus pneumoniae and in other Gram-positive bacteria containing mef/mel(msr(D)) elements. PLoS One, 2015; 10(2): e0116254: 1-23.

11. Youn YS, Lee KY, Mycoplasma pneumoniae pneumonia in children. Korean J Pediatr., 2012; 55(2): 42-47.

12. Yang D, Chen L, Chen Z, The timing of azithromycin treatment is not associated with the clinical prognosis of childhood Mycoplasma pneumoniae pneumonia in high macrolide-resistant prevalence settings. Plos One, 2018; 13(1): e0191951: 1-7.

13. Liu Y, Ye X, Zhang H, Xu X, Li W, Zhu D, Wang M, Characterization of macrolide resistance in Mycoplasma pneumoniae isolated from children in Shanghai, China. Diagn Microbiol Infect Dis., 2010;67(4): 355-858.

14. Li X, Atkinson TP, Hagood J, Makris C, Duffy LB, Waites KB, Emerging macrolide resistance in Mycoplasma pneumoniae in children: detection and characterization of resistant isolates. Pediatr Infect Dis J., 2009; 28(8): 693-696.

15. Hsieh YC, Tsao KC, Huang CG, Tong S, Winchell JM, Huang YC, Shia SH, Lai SH, Lin TY, Lifethreatening pneumonia caused by macrolide-resistant Mycoplasma pneumoniae. Pediatr Infect Dis J., 2012; 31(2): 208-209.

16. Gin A, Dilay L, Karlowsky JA, Walkty A, Rubinstein E, Zhanel GG, Piperacillin-tazobactam: a beta-lactam/ beta-lactamase inhibitor combination. Expert Rev Anti Infect Ther., 2007; 5(3):365-383.

17. Philippe J, Gallet B, Morlot C, Denapaite D, Hakenbeck R, Chen Y, Vernet T, Zapun A, Mechanism of $\beta$-lactam action in Streptococcus pneumoniae: the piperacillin paradox. Antimicrob Agents Chemother., 2015; 59(1): 609-621.

18. Ryu S, Klein EY, Chun BC, Temporal association between antibiotic use and resistance in Klebsiella pneumoniae at a tertiary care hospital. Antimicrob Resist Infect Control., 2018; 7(1): 83: 1-6.

19. Harris PNA, Tambyah PA, Lye DC, Mo Y, Lee TH, Yilmaz M, Alenazi TH, Arabi Y, Falcone M, Bassetti M, Righi E, Rogers BA, Kanj S, Bhally H, Iredell J, Mendelson M, Boyles TH, Looke D, Miyakis S, Walls G, Al Khamis M, Zikri A, Crowe A, Ingram
P, Daneman N, Griffin P, Athan E, Lorenc P, Baker P, Roberts L, Beatson SA, Peleg AY, Harris-Brown T, Paterson DL; MERINO Trial Investigators and the Australasian Society for Infectious Disease Clinical Research Network (ASID-CRN), Effect of Piperacillin-Tazobactam vs Meropenem on 30-Day Mortality for Patients With E coli or Klebsiella pneumoniae Bloodstream Infection and Ceftriaxone Resistance: A Randomized Clinical Trial. JAMA, 2018; 320(10): 984-994.

20. Stainton SM, Monogue ML, Nicolau DP, In VitroIn Vivo Discordance with Humanized PiperacillinTazobactam Exposures against Piperacillin-TazobactamResistant/Pan- $\beta$-Lactam-Susceptible Klebsiella pneumoniae Strains. Antimicrob Agents Chemother., 2017;61(7):e00491-17: 1-4.

21. Sugimoto N, Yamagishi Y, Hirai J, Sakanashi D, Suematsu H, Nishiyama N, Koizumi Y, Mikamo H, Invasive pneumococcal disease caused by mucoid serotype 3 Streptococcus pneumoniae: a case report and literature review. BMC Res Notes, 2017;10(1): 21: 1-6.

22. Kuti JL, Wang Q, Chen H, Li H, Wang H, Nicolau DP, Defining the potency of amikacin against Escherichia coli, Klebsiella pneumoniae, Pseudomonas aeruginosa, and Acinetobacter baumannii derived from Chinese hospitals using CLSI and inhalation-based breakpoints. Infect Drug Resist., 2018; 11: 783-790.

23. Yang D, Chen L, Chen Z, The timing of azithromycin treatment is not associated with the clinical prognosis of childhood Mycoplasma pneumoniae pneumonia in high macrolide-resistant prevalence settings. Plos One, 2018; 13(1): e0191951: 1-7.

24. Boboia A, Florea LS, Turcu-Stiolica A, Tăerel AE, Rais C, Revnic C, Florea A, Vedeanu NS, Nastasă C, Oniga O, Decision analysis of antibiotic use. Farmacia, 2020, 68(4): 757-765.

25. Sharifi-Rad J, Rodrigues CF, Stojanović-Radić Z, Dimitrijević M, Aleksić A, Neffe-Skocińska K, Zielińska D, Kołożyn-Krajewska D, Salehi B, Milton Prabu S, Schutz F, Docea AO, Martins N, Calina D, Probiotics: Versatile Bioactive Components in Promoting Human Health. Medicina (Kaunas), 2020; 56(9): 433: 1-30.

26. Spătaru RI, Martius E, Ivan LE, Sîrbu D, Hostiuc S, Pseudomembranous colitis complicating the natural course of Crohn's disease in a pediatric patient. Rom J Leg Med., 2014; 22(3): 161-166. 